\title{
Tifinagh and consonantal writing systems
}

\section{Eugene Buckley \\ UNIVERSITY OF PENNSYLVANIA}

\section{Linguistic setting}

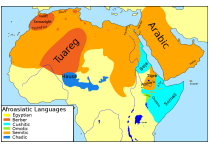

\section{Afro-Asiatic}

- A large family of languages across North Africa and the Middle East.

- Consonantal-root morphology, famous especially from Semitic.

\section{Berber}

- One branch of Afro-Asiatic.

- Multiple languages across the Maghreb (western North Africa).

- Tuareg in a large region of the Sahara and Sahel.

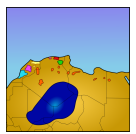

Tarifit Tamazight III Tashelhiyt Tamasheq Chenou Kabyle Chaouia - Saharan Berber

\section{Tuareg}

- A semi-nomadic people of the western Sahara and neighboring Sahel.

- Local names reflect historical sound changes.

- Tamahaq, Tahaggart

Algeria, Libya, Niger - 62,000 speakers

- Tamajaq. Tawallammat

Niger, Mali $-640,000$ speakers

- Tamajeq, Tayart

Niger - 250,000 speakers

- Tamasheq

Mali, Burkina Faso - 281,200 speakers

- The language is sometimes collectively called Tamashek / Tamasheq.

- The point of interest here is the use of the traditional Tifinagh script by the Tuareg to write their language.

\section{References}

Aghali-Zakara, Mohamed (1994). Graphèmes berbères et dilemme de diffusion: Interaction des alphabets latin, ajami et tifinagh. Etudes et Documents Berberes 11, 107-121.

Cohen, Marcel. 1958. La grande invention de l'écriture et son évolution, plate 39.

Daniels, Peter T. 2000. Syllables, consonants, and vowels in West Semitic writing. Lingua Posnaniensis 42, 43-55. Foucauld, Charles de. 1952. Dictionnaire touareg-français. Dialecte de l'Ahaggar. Impr. nationale de France. Gelb, Ignace J. 1963. A study of writing. University of Chicago Press.

Hanoteau, Adolphe. 1896. Essai de grammaire de la langue tamachek'. Algiers: Adolphe Jourdan.

Prasse, Karl-G. 1972. Manuel de grammaire touarégue (tăhăggart). Université de Copenhague.

Priest, Lorna A.; Jon Coblentz; Andrew Savage. 2008. Proposal to encode additional Tifinagh characters.

Swiggers, Pierre. 1984. On the nature of the West-Semitic writing systems. Aula orientalis 2, 149-151.

\section{Scripts}

\section{Libyco-Berber (Numidian)}

- An ancient script of disputed origin.

- Most likely from Phoenician, perhaps via Iberia.

- Mainly attested in Algeria and Tunisia.

- Rock inscriptions often difficult to date.

- May have originated by the $6^{\text {th }}$ century BCE, or even earlier.

- Only consonants are represented, to the extent the texts are understood.

- E.g., Punic names ?nkn, Pšyn, ?rš = V-initial Libyco-Berber nkn, šyn, rš.

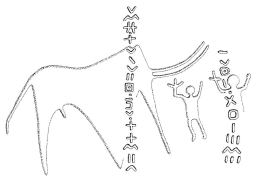

gwytt $\cdot \mathrm{mdn} \cdot \mathrm{bwm}$ ?mt $\cdot \mathrm{z}_{1} \mathrm{ym}$ hyhz ${ }_{2}$ rt $\cdot \mathbf{z}_{2}$ bmn

(written from the bottom up)

Oukaïmeden, Morocco $<$ lbi-project.org>

\section{Traditional Tifinagh}

- Descended from Libyco-Berber, through long period of minimal attestation.

- Some letters differ graphically or in their phonetic value.

- In Niger, also called Shifinagh.

- Used today by the Tuaregs mainly for symbolic or playful purposes.

- Only consonants are written, except for many word-final vowels.

In this photo, the city name Kidal (in Mali) is written kdl from left to right.

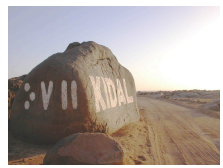

\section{Neo-Tifinagh}

- A recently proposed, standardized version of the script with vowel letters.

- Structurally a simple alphabet, not an abjad.

- Limited use in Morocco and Algeria for Northern Berber.

At right, Tifinar written in this alphabet, with vowel letters $\mathbf{i}$ and $\mathbf{a}$. 


\section{Typology}

\section{The Semitic abjad}

- An abjad is a writing system that represents just (or mainly) consonants.

- The West Semitic script family, ultimately inspired by Egyptian.

- Phoenician is a pure form, representing only consonants.

- katti "I was" written $+x_{1}=\mathbf{k t}$.

- Hebrew, like most abjads, writes some vowels.

- The otherwise consonantal letters $\mathbf{y} \mathbf{w} \mathbf{h}$ as matres lectionis.

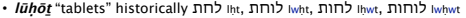

\section{A syllabary?}

- Gelb (1963): writing systems evolve unidirectionally over time.

- Logographic > syllabic > alphabetic.

- Cannot skip a step, or go in reverse.

- West Semitic is derived from Egyptian consonantal signs.

- Egyptian phonograms < logograms, therefore must be syllabic.

- Semitic yielded the Greek alphabet (syllabic > alphabetic).

- Under this view, the West Semitic script is a syllabary.

- CV signs in which the vowel is indeterminate, and can be zero.

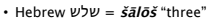

- As a consonantal alphabet (abjad): šlš

- As a syllabary with unmarked vowels: $\breve{\mathbf{s}}^{x} \times \breve{s}^{x}(\rightarrow$ ša|ošø

- Matres have to be treated as phonetic complement to syllabic sign.

\section{Syllable structure}

- Partly this works because (ancient) Semitic syllables all begin with C.

- Every syllable therefore has at least one consonant, and letter.

- Many have rejected the syllabic analysis (Daniels 2000).

- Complications such as this needed to resolve contradictions.

- But a compromise position (Swiggers 1984):

- The letter DENOTES a consonant, but STANDS FOR a syllable.

- True even in borrowings of a script to languages with V-initial syllables.

- Adaptations of Arabic: initial alif occurs in vowel-initial words.

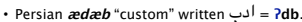

- Malay əmas "gold" written امس أ ?ms.

- A letter therefore still STANDS FOR that syllable.

- But in Tifinagh no such marker exists.

- An important proof of the abjad as a true segmental system.

\section{Tifinagh writing}

$: 1: 0$ I $\wedge \wedge:+1+$

w nk fddw tnt

awa nək fadudu tənnat

this (is) me Fedudu saying

ill:। CI $\odot: \Sigma \vdots \wedge ~ \|: C \ominus$ 。

hlyn šf swy hd lyšba

hulayin šif siwi hid elyəšaba

I.greet.there the.chief send.me here the.clothing

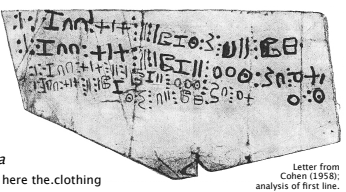

- Initial, internal, and some final vowels are omitted.

- This results in unrepresented initial syllables: note $\mathbf{w}$ for awa "this".

- Same is true in Lybico-Berber.

- In more limited way, also found in Orkhon (Old Turkish) runes.

- Many final vowels are written by special a sign, or $y \mathbf{w}$ for $i u$.

- Notably, these do not function to represent a syllable, just the V of CV.

\section{Complex linguistic structure}

- Tifinagh mainly represents consonants, but also some vowels word-finally.

- Already the constituents C, V, and Word are implicated.

- Syllables are not directly represented. More examples of unwritten initial V:

- Singular ehakit "tent" as : $:+$ hkt ; plural ihaktan as $\$ *+1$ hktn

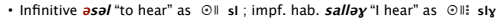

- But syllabification does matter in whether a segment is C or V.

- Vowel in inya "he killed" is not written: 1: . nya (Hanoteau 1896)

- Glide in alos wa ynya "the man he killed" is: $11 \odot: \Sigma 1 !$. Is w ynya

- Word-internal vowels are not directly written, but they play another role.

- Ligatures are used for certain adjacent consonants. (Priest, et al. 2008)

- inbal "he buried" as $\ominus \|$ пы ; tastəq "song" as $+\oplus::$ tstq

- Loanword fanta "Fanta" as It. fñta (Aghali-Zakara 1994)

- Unwritten V prevents the use of a ligature in CVC.

- anabal "burial" as IФ\| nbl ; tasetəq "infection" as $+\odot+::$ tstq

- Loanword limonat "lemonade" as IICI+ Imnt

- Some writers may not strictly observe this practice. (Prasse 1972)

- The rich constituent structure of spoken language provides many categories that can play a role in writing systems.

- The syllable is decidedly less important in Tifinagh.

- Swiggers' compromise reflects a fact of Semitic syllables.

- Not an inherent property of an abjad.
LSA Annual Meeting, Baltimore

January 9, 2010

gene@ling.upenn.edu
Department of Linguistics

619 Williams Hall

University of Pennsylvania

Philadelphia, PA 19104-6305 